American Journal of Applied Sciences 9 (7): 993-999, 2012

ISSN 1546-9239

(C) 2012 Science Publications

\title{
Physico-Chemical Characteristics of Date Seed Oil Grown in Sudan
}

\author{
${ }^{1}$ Rehab Salih Mahmoud Abdalla, ${ }^{2}$ Alsheikh AlGilani Albasheer, \\ ${ }^{3}$ Abdel Rahim Mohamed ELHussein and ${ }^{4}$ ELrasheed Ahmed Gadkariem \\ ${ }^{1}$ Ministry of Science and Technology, Central Lab, Khartoum, Sudan \\ ${ }^{2}$ Department of Chemistry, Faculty of Science, \\ University of Alzaiem Alazhari, Khartoum, Sudan \\ ${ }^{3}$ Ministry of Animal Resources and Fisheries Animal Resources Research Corporation, \\ Director General Office Khartoum, Sudan \\ ${ }^{4}$ ELRibat National University, Faculty of Pharmacy Khartoum, Sudan
}

\begin{abstract}
Problem statement: Studies were conducted on the physical-chemical properties of Sudanese date seed oil extracted from two date palm cultivars (Phoenix dactylifera L.) ALBarakawi and Alqundeila. The extracted oil from ALBarakawi seeds weighed $6.833 \%$ w/w oil, Alqundeila oil extracted weighed 5.064\% w/w. Approach: The physical properties of ALBarakawi oil were: viscosity: 17cp, refractive Index: 1.444 , density: $0.9116 \mathrm{~g} \mathrm{~cm}^{-3}$ color: Within the range 1. 6-11.1 (red-yellow). For Alqundeila the physical properties were: viscosity: 20cp, refractive index: 1.458 , density: $0.9174 \mathrm{~g} \mathrm{~cm}^{-3}$ color: 1.8-12.1 (red yellow). Results: The chemical properties were: Acid value 2.55, saponfication value $0.255 \mathrm{mg} \mathrm{g}^{-1}$, iodine value $71.12 \mathrm{gm}_{2} / 100 \mathrm{gm}$ fat, peroxide value: $4.8 \mathrm{mg}$. Peroxide/Kgoil for ALBarakawi. For Alqundeila they were: acid value 2.47 , saponfication value $0.267 \mathrm{mg} \mathrm{g}^{-1}$ and iodine value $83.31 \mathrm{gm} \mathrm{I}_{2} / 100 \mathrm{gm}$ fat, peroxide value: $7.4 \mathrm{mg}$ Peroxide/Kgoil. In this study, High Performance Liquid Chromatography (HPLC) was utilized for the identification and quantification of vitamin $\mathrm{E}$ in these samples. The content of vitamin E for ALBarakawi was 5.821 and $6.054 \mathrm{ppm}$ for Alqundeila. For the fatty acid content in these oils, Gas Chromatography-Mass Spectrometry (GC-MS) was used. The constituents of fatty acids (calculated \% relative to total fatty acid constituents) in ALBarakawi were: Saturated lauric acid $37.10 \%$, palmitic acid: $9.24 \%$, Stearic acid 1.71\%, Unsaturated fatty acids: Linoleic acid (Omega-6) 4.33\%, Oleic acid (Omega-9) 32.66\%. For Alqundeila, the found fatty acids were: Saturated lauric acid $0.11 \%$, Palmitic acid: $0.42 \%$, Stearic acid 46.93\%. Conclusion/Recommendations: The elements types and contents in these oils were: Iron 0.27 ppm, Magnesium 0.204 ppm, Sodium 60 ppm, Potassium 470 ppm, Calcium 25 ppm, Selenium 34.4 ppb for ALBarakawi. The contents of these elements in Alqundeila were: iron 0.27 ppm Magnesium 0.07 ppm, Potassium 2.3 ppm, Selenium 12.6 ppb. The methods involved in this study covered, Gas Chromatography-Mass Spectrometry (GC-MS), High Performance Liquid Chromatography (HPLC), Atomic Absorption Spectroscopy (AAS) and Refractometry. Physico-chemical properties of date seed oil reported in this study were found similar to most of the early published results in this field.
\end{abstract}

Key words: Gas Chromatography-Mass Spectrometry (GC-MS), High Performance Liquid Chromatography (HPLC), non-natural source, date seeds oil

\section{INTRODUCTION}

Return to the natural sources of various food constituents (vitamins, minerals, fats, proteins....). Is becoming the target for researchers throughout the world.This return is caused by the growing recognition of hazards to the human health by foods of non-natural source. The palm tree date forms one of the sources of food for humans and animals in addition to its economic benefits. Most of the Mediterranean and Arabian Peninsula countries are considered date producing countries. Sudan is also ranked among these countries. Different types of local palm trees are grown in Sudan. They are named ALBarakawi-AlqundeilaALMishriq wad Khatib-wad Laqai-ALTamudhah AL Kullimah. The fruit of the date is composed of a fleshy peri-carp and seed. The date seeds as in most counties was finding little use as no research work was done on

Corresponding Author: ELrasheed Ahmed Gadkariem, ELRibat National University, Faculty of Pharmacy Khartoum, Sudan 993 
its possible useful constituents. However recent work including work done by (Besbes et al., 2005; 2004a; 2004b; Chiew et al., 2007; Devshony et al., 1992) proved that date seeds have extractable high value added components. The potential uses of date seed and its constituents are expected to cover uses in cosmetics, medicine, pharmaceuticals, feed and food industries (Harry, 1936; Salem and Hegazi, 1971; E1-Shurafa et al., 1982; Whaibi et al., 1985; Whaibi and Basalah, 1986; Mossa et al., 1986). The literature survey revealed that no previous work was done on Sudanese palm tree seeds oil to evaluate its physico-chemical characteristics or any other possible potential applications. The aim of this work was to extract date seed oil and study its quality characteristics in two selected palm tree types named ALBarakawi and Alqundeila. This work was also intended to stimulate further research on date seed oil to cover stability, phenolic compounds contents and to point out a constituent that can be considered a marker for the different type palm of trees in Sudan.

\section{MATERIALS AND METHODS}

\section{Materials:}

Seeds collection: The seeds of two cultivars: ALBarakawi and Alqundeila were collected from a local date's market at Omdurman city. (Major source of the collected dates is Northern Sudan).

\section{Extraction methods:}

Oil extraction and preparation: Weights of about 750-900g of ALBarakawi and Alqundeila seeds were used for oil extraction. The seeds were separated from the fruits, dried and crushed into minute granules using automatic machine (retsch-100) for $3 \mathrm{~m}$. Total lipids were extracted from the seeds with hexane using Soxhlet apparatus. The extraction process continued for 4-6 h. The solvent was evaporated on rotary evaporator under reduced pressure and the produced oil (free from nhexane) was collected, weighed, stored in a dark container in a deep-freeze $\left(-20^{\circ} \mathrm{C}\right)$ till subsequent analyses.

Fatty acids composition: The oil fatty acid methyl esters were prepared as described in Christie (AOAC, 1990). One $\mathrm{ml}$ of the produced oil was added to seven $\mathrm{ml}$ methanolic $\mathrm{NaoH}(0.5 \mathrm{M})$ followed by seven $\mathrm{ml}$ of methanolic $\mathrm{H}_{2} \mathrm{SO}_{4}$ before shaking. The solution was left overnight. Two $\mathrm{ml}$ of $\mathrm{n}$-hexane or heptane was added to the reaction mixture followed by saturated $\mathrm{NaCl}$. This mixture was shaken well and allowed to separate into two layers. One $\mathrm{ml}$ from the upper layer was transferred to a new tube and dried with anhydrous $\mathrm{Na}_{2} \mathrm{SO}_{4}$.
Analytical methods:

Viscosity determination: Viscosity was determined at $30^{\circ} \mathrm{C}$ using HAAKE viscometer 6 plus (thermoelectron corporation instrument type 387-0100).

Determination of Refractive index: The Refractive index was determined by using BELLINGHAM and STANLEY L LD $^{\mathrm{TD}}$ LONDON-(No 918095 MADE in ENGLAND, instrument). Refractometer was adjusted first, using distilled water.

Density determination: Density was measured using Puchnometer Kit for AEP balances, (Adam Equipment co.L ${ }^{\mathrm{TD}}$. Bond Avenue Denbigh East Estate Milton Keynes, MK, ISV-united kingdom. (AEP-250g-max $\left.250 \mathrm{~g}^{-1}\right), \mathrm{d}=1 \mathrm{mg}$, density determination $=\mathrm{g} / \mathrm{c}^{3}$ ).

Colour determination: The Colour was determined by using Lovibond or Tintometer typed" instrument (Tintometer $\mathrm{L}^{\mathrm{TD}}$. The colour laboratory Salisbury England).

Vitamin $\mathrm{E}$ identification and determination by HPLC and GC-mass: Vitamin $\mathrm{E}$ in the oil sample (0.2 $\mathrm{gm} \mathrm{mL}^{-1}$ solution in $\mathrm{n}$-hexane) was identified and evaluated by HPLC and GC-mass. The quantification of Vitamin $\mathrm{E}$ in the oils was determined using standard vitamin E solution containg 2000 ppm diluted to obtain a calibration curve ranging between 20-2000 ppm.

HPLC system: Analyses were carried out using Water/U.S.A600 High Performance Liquid Chromatography (HPLC), pump 600, Detector 2969 Photo Diode Array (PDA) Stationary phase: Normal Phase Silica (NP-HPLC)Column $(4.6 \times 150 \mathrm{~mm})$, flow rate $1.0 \mathrm{~mL}$ min. Injector volume $20 \mu \mathrm{L}^{-1}$, Wavelength $295 \mathrm{~nm}$. Mobile Phase composition:

(n- hexane + THF +2 - propanol) $(500+30+2)$

GC-Mass system: Analyses were carried out using a Varian 450 Gas chromatography equipped with Varian 220-IT Mass spectrometer and VF-5 ms capillary column $(30 \times 0.25 \mathrm{~mm} ; 0.25 \mathrm{um}$ film thickness). The oven temperature was held at $50^{\circ} \mathrm{C}$ for $5 \mathrm{~min}$ and programmed at $7^{\circ} \mathrm{C} / \mathrm{min}$ to $300^{\circ} \mathrm{C}$ for $5 \mathrm{~min}$. Other operating conditions were: Helium gas carrier at a flow rate of $1.0 \mathrm{~mL}^{-1} \mathrm{~min}$. injector and detector temperature were 250 and $280^{\circ} \mathrm{C}$ respectively; split ratio 1:50. Mass spectra were taken at 70 ev mass ranges from $\mathrm{m} / \mathrm{z}$ 40-400 amu.

GC-MS identification and determination of fatty acids methyl esters in the oils: Gas Chromatography 
Mass Spectrometer was performed using Shimadzu instrument (GC-MS-QP-2010) fitted with electron impact (EI $1.70 \mathrm{ev)}$ mode. The analytical column was RTX 5 (5\% phenyl-95\% dimethyl polysiloxane with length of $30 \mathrm{~m} \times 0.25 \mu \mathrm{m}$ ). Helium gas was used as a carrier gas at a flow rate of $1 \mathrm{~mL} \mathrm{~min}{ }^{-1}$. the temperature was programmed at $40^{\circ} \mathrm{C}$ for $0 \mathrm{~min}$ then increased to $150^{\circ} \mathrm{C}$ at the rate of $15^{\circ} \mathrm{C} / \mathrm{min}$ with hold time $5 \mathrm{~min}$ then increased to $250^{\circ} \mathrm{C}$ with hold time $10 \mathrm{~min}$. The temperature of injector was $250^{\circ} \mathrm{C}$.

AAS identification and determination of elements in the oils: Atomic Absorption Spectroscopy was performed using Shimadzu instrument (AAS-6800).

For the $\mathrm{Mg}, \mathrm{Fe}, \mathrm{Ca}, \mathrm{Na}, \mathrm{K}, 10 \mathrm{~mL}$ oil sample was dissolved in $1 \mathrm{~mL}$ carbon tetra Chloride $\left(\mathrm{CCL}_{4}\right)$.

To this solution $10 \mathrm{~mL}^{-1} 10 \% \mathrm{v} / \mathrm{v}$ nitric acid was added, mixed well for about $10 \mathrm{~m}$ before centrifugation at 2500-3000 revolution per minuets for $2 \mathrm{~m}$. The supernatant was then separated and the nominated elements were determined by AAS with reference to their respective standards. For selenium the same above procedure was followed but using nickel sulphate $0.25 \mathrm{gm}$ dissolved in $10 \mathrm{~mL}$ of $10 \% \mathrm{v} / \mathrm{v}$ nitric acid (Price, 1979).

\section{RESULTS}

Table 1 reflects the physico-chemical characteristics of the extracted seeds oil of the two date palm cultivars (ALBarakawi and Alqundeila) compared with characteristics of some reported values cited in the Literature (Besbes et al., 2005; Devshony et al., 1992).

The oil was a semi-solid at temperatures below $10^{\circ} \mathrm{C}$ and a viscous liquid at a ambient temperature.

The fatty acids $\%$ content calculated using internal normalization method (in descending order were) lauric acid (37.10\%), Oleic acid (32.66\%), Methyl tetradecanoate (14.73\%), Palmitic acid (9.24\%), Linoleic acid (4.33\%), Stearic acid (1.71\%) and finally 1, 2 Benzenedicarboxylic acid (phthalic acid) $(0.22 \%)$..

Figure 1 reflects a typical GC chromatogram of the separated fatty acids and Table 2 reflects their relevant retention times.

Figure 2a shows a peak for $\alpha$ - tocopherols at about 2.5 min retention time for the standard. Figure $2 \mathrm{~b}$ shows typical chromatogram of sample showing vitamin E at: (RT: 2.535) and a number of unidentified peaks.

Table: 1 Reflects the summarised physico-chemical properties of the two oils compared with previously reported results

\begin{tabular}{|c|c|c|c|c|c|c|}
\hline \multirow{3}{*}{$\frac{\text { Date seeds oils }}{\text { oil extracted }}$} & \multicolumn{6}{|l|}{ Cultivars } \\
\hline & \multirow{2}{*}{$\frac{\text { ALBarakawi }}{6.833 \% \mathrm{w} / \mathrm{w}}$} & \multirow{2}{*}{$\frac{\text { Alqundeila }}{5.064 \% \mathrm{w} / \mathrm{w}}$} & \multicolumn{2}{|c|}{ Besbes et al. (2005) } & \multicolumn{2}{|c|}{ s.Devshony et al. (1992) } \\
\hline & & & $\mathrm{NR}^{*}$ & $\mathrm{NR}^{*}$ & $8.40 \%$ & $8.13 \%$ \\
\hline Viscosity & $17 \mathrm{cp}$ & $20 \mathrm{cp}$ & 18. 50mpa.s & 20. 50mpa.s & $\mathrm{NR}^{*}$ & $\mathrm{NR}^{*}$ \\
\hline Refractive Index at $\left(20^{\circ} \mathrm{C}\right.$ & 1.444 & 1.458 & 1.457 & 1.462 & $\mathrm{NR}^{*}$ & $\mathrm{NR}^{*}$ \\
\hline Density & $0.9116 \mathrm{~g} / \mathrm{cm}^{3}$ & $0.9174 \mathrm{~g} / \mathrm{cm}^{3}$ & $\mathrm{NR}^{*}$ & $\mathrm{NR}^{*}$ & $\mathrm{NR}^{*}$ & $\mathrm{NR}^{*}$ \\
\hline Colour & 1. $6-11.1$ & $1.8-12.1$ & $\mathrm{NR}^{*}$ & $\mathrm{NR}^{*}$ & $\mathrm{NR}^{*}$ & $\mathrm{NR}^{*}$ \\
\hline Acid value (mgKOH/goil & 2.55 & 2.47 & $\mathrm{NR}^{*}$ & $\mathrm{NR}^{*}$ & $\mathrm{NR}^{*}$ & $\mathrm{NR}^{*}$ \\
\hline Specification value & $0.255 \mathrm{mg} / \mathrm{g}$ & $0.267 \mathrm{mg} / \mathrm{g}$ & $\mathrm{NR}^{*}$ & $\mathrm{NR}^{*}$ & $\mathrm{NR}^{*}$ & $\mathrm{NR}^{*}$ \\
\hline Iodine value (Wijs) & $71.12 \mathrm{gm} \mathrm{I}_{2} / 100 \mathrm{gm}$ fat & $83.31 \mathrm{gm} \mathrm{I}_{2} / 100 \mathrm{gm}$ fat & $45.49 \mathrm{~g} / 100 \mathrm{~g}$ & $44.08 \mathrm{~g} / 100 \mathrm{~g}$ & & \\
\hline Peroxide value & $4.8 \mathrm{mg}$.Peroxide $/ \mathrm{kg}$ oil & 7.4 mg.Peroxide $/ \mathrm{Kg}$ oil & $\mathrm{NR}^{*}$ & $\mathrm{NR}^{*}$ & $\mathrm{NR}^{*}$ & $\mathrm{NR}^{*}$ \\
\hline Vitamin $\mathrm{E}^{\mathrm{HPLC}}$ & $5.821 \mathrm{ppm}$ & $6.054 \mathrm{ppm}$ & $24.97 \pm 1.40$ & $38.85 \pm 1.80$ & $\mathrm{NR}^{*}$ & $\mathrm{NR}^{*}$ \\
\hline Vitamin $\mathrm{E}^{\mathrm{GC}-\mathrm{MASS}}$ & Structure Vit E & Structure Vit E & $\mathrm{NR}^{*}$ & $\mathrm{NR}^{*}$ & $\mathrm{NR}^{*}$ & $\mathrm{NR}^{*}$ \\
\hline \multicolumn{7}{|l|}{ Fatty acid ${ }^{\mathrm{d}}$} \\
\hline lauric acid & $37.10 \%$ & $0.11 \%$ & $24.34 \%$ & $22.56 \%$ & $24.00 \%$ & $19.6 \%$ \\
\hline Palmitic acid & $9.24 \%$ & $0.42 \%$ & $\mathrm{NR}^{*}$ & $\mathrm{NR}^{*}$ & $9.6 \%$ & $10.20 \%$ \\
\hline Stearic acid & $1.71 \%$ & $46.93 \%$ & & & $1.30 \%$ & $1.90 \%$ \\
\hline Oleic acid (Omega-9) & $32.66 \%$. & $\mathrm{Nd}^{*}$ & $39.17 \%$ & $42.13 \%$ & $41.10 \%$ & $44.10 \%$ \\
\hline Linoleic acid (Omega-6) & $4.33 \%$ & $\mathrm{Nd}^{*}$ & $\mathrm{NR}^{*}$ & $\mathrm{NR}^{*}$ & $14.5 \%$ & $12.00 \%$ \\
\hline \multicolumn{7}{|l|}{ Mineral in oils } \\
\hline Iron & $0.27 \mathrm{ppm}$ & $0.27 \mathrm{ppm}$ & $\mathrm{NR}^{*}$ & $\mathrm{NR}^{*}$ & $1.68 \%$ & $0.78 \%$ \\
\hline Magnesium & $0.204 \mathrm{ppm}$ & $0.07 \mathrm{ppm}$ & $\mathrm{NR}^{*}$ & $\mathrm{NR}^{*}$ & $7.78 \%$ & $6.74 \%$ \\
\hline Sodium & $60 \mathrm{ppm}$ & $\mathrm{Nd}^{*}$ & $\mathrm{NR}^{*}$ & $\mathrm{NR}^{*}$ & $1.48 \%$ & $1.37 \%$ \\
\hline Potassium & $470 \mathrm{ppm}$ & $2.3 \mathrm{ppm}$ & $\mathrm{NR}^{*}$ & $\mathrm{NR}^{*}$ & $25.40 \%$ & $28.90 \%$ \\
\hline Calcium & $25 \mathrm{ppm}$ & $\mathrm{Nd}^{*}$ & $\mathrm{NR}^{*}$ & $\mathrm{NR}^{*}$ & $1.58 \%$ & $1.87 \%$ \\
\hline Selenium & $34.4 \mathrm{ppb}$ & $12.6 \mathrm{ppb}$ & $\mathrm{NR}^{*}$ & $\mathrm{NR}^{*}$ & $\mathrm{NR}^{*}$ & $\mathrm{NR}^{*}$ \\
\hline
\end{tabular}

$\mathrm{Oil}^{\text {phc }}$ : physico-chemical, $\mathrm{Nd}^{*}:$ Not detected, NR: Not reported, Fattyacid ${ }^{\mathrm{d}}:$ percent by weight of total fatty acids 
Am. J. Applied Sci., 9 (7): 993-999, 2012

Gas Chromatography mass spectrometer QP-2010-SHIMADZU

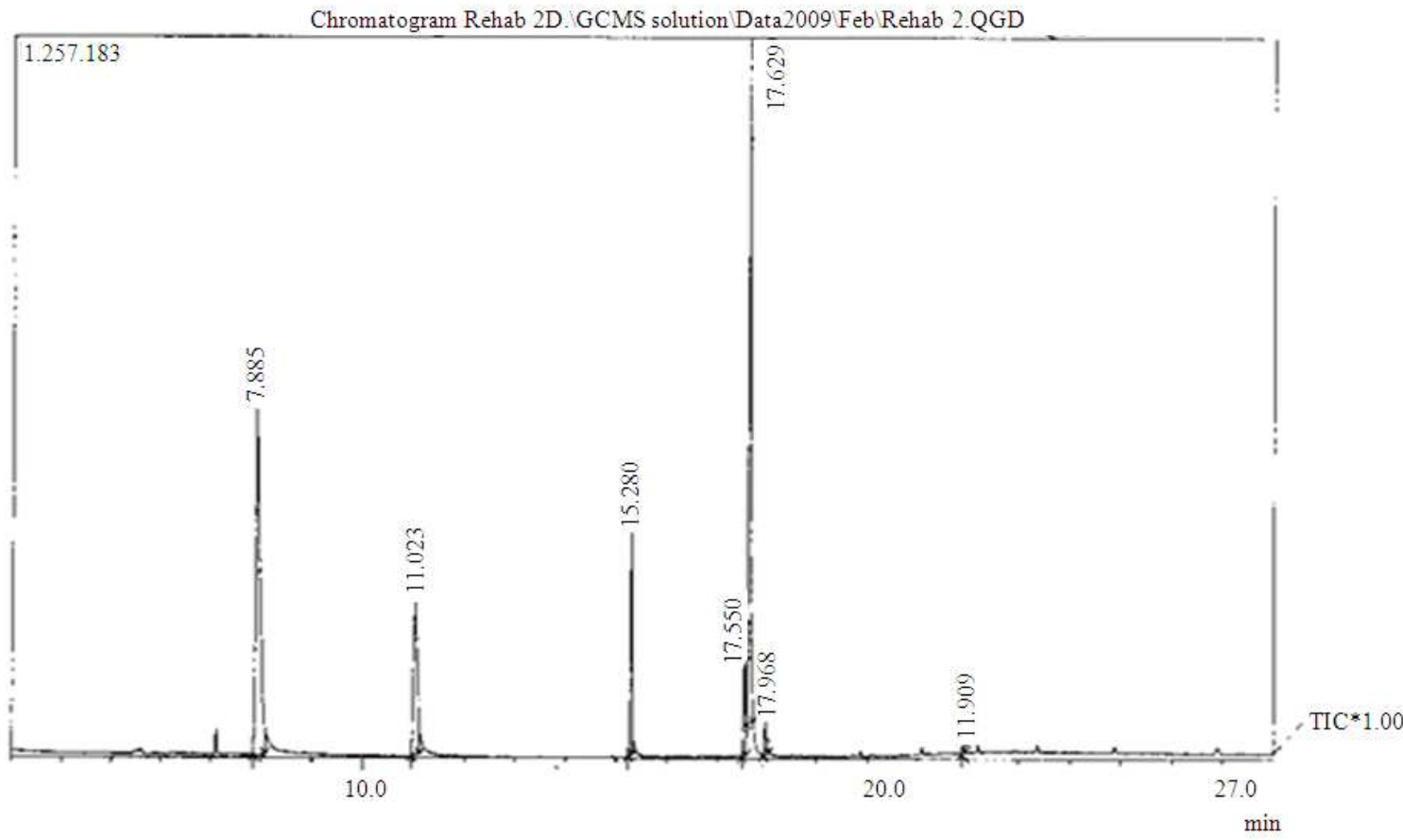

Fig. 1: Typical GC- mass chromatogram of separated fatty acids

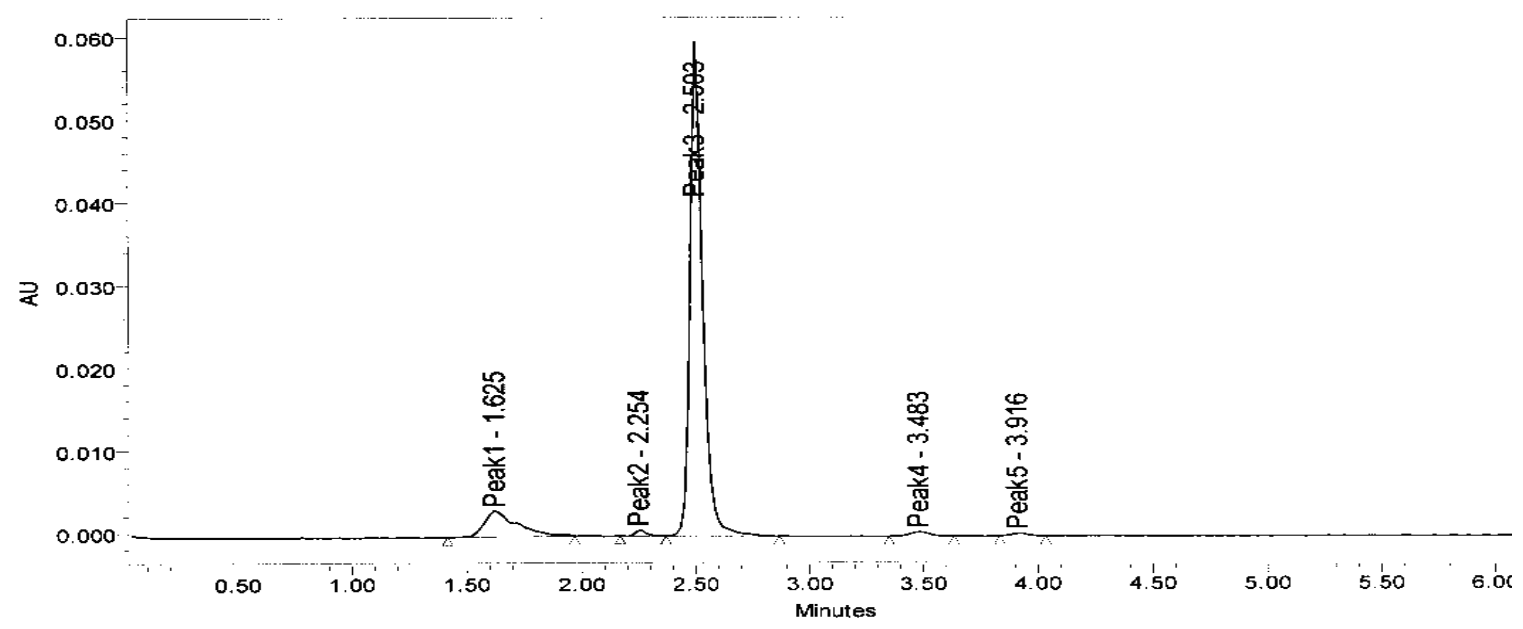

\begin{tabular}{|l|l|c|r|r|r|}
\hline & Peak Name & RT & Area & \% Area & Height \\
\hline 1 & Peak1 & 1.625 & 31292 & 11.53 & 3120 \\
\hline 2 & Peak2 & 2.254 & 2570 & 0.95 & 677 \\
\hline 3 & Peak3 & 2.503 & 232340 & 85.64 & 56753 \\
\hline 4 & Peak4 & 3.483 & 3292 & 1.21 & 524 \\
\hline 5 & Peak5 & 3.916 & 1812 & 0.67 & 306 \\
\hline
\end{tabular}




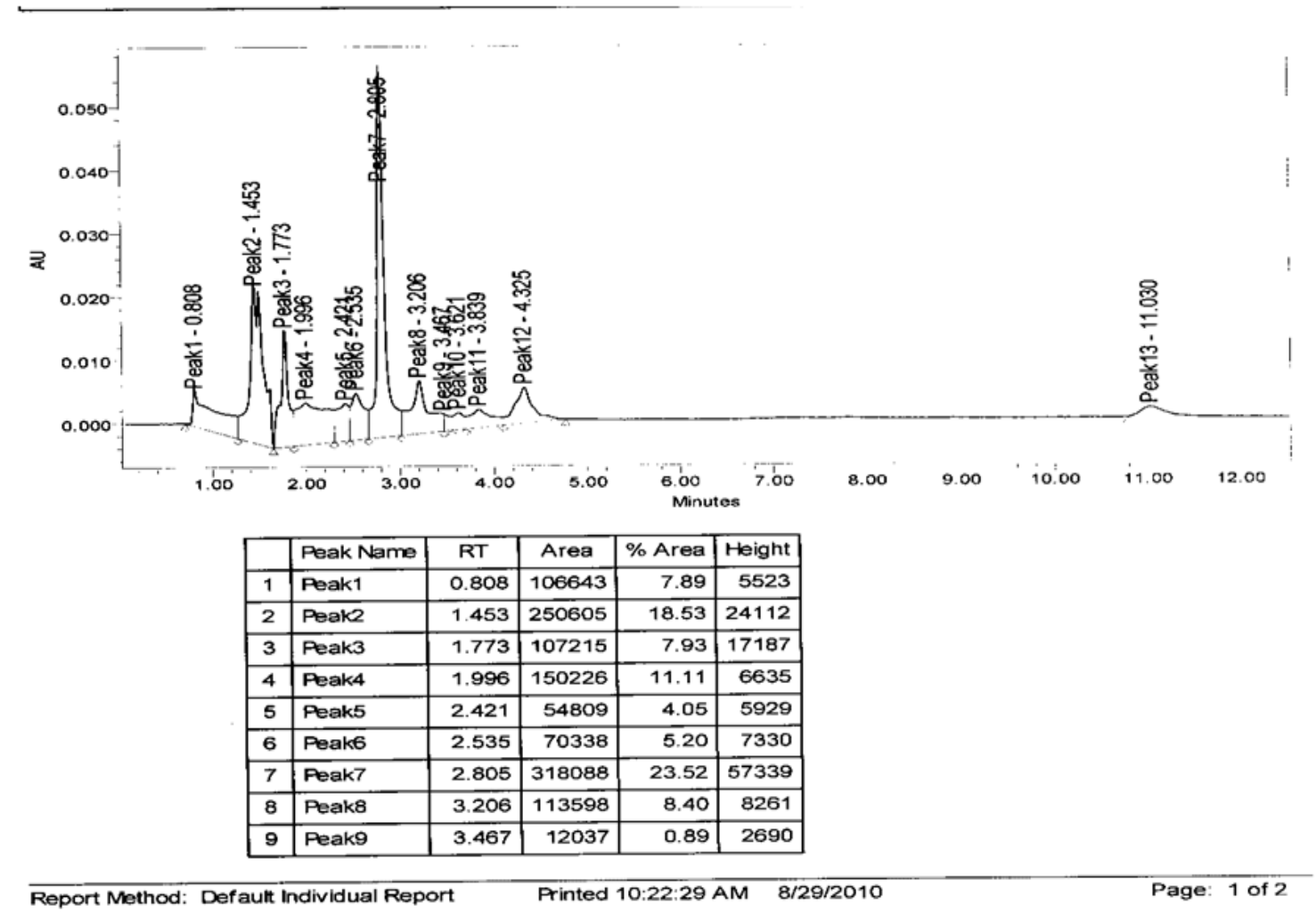

(b)

Fig. 2a: Typical chromatogram of standard vitamin E (RT: 2.503) (b) Typical chromatogram of sample showing vitamin E at: (RT: 2.535)

Table 2: Reflects the retention times for the GC-mass separated fatty acids

\begin{tabular}{|c|c|c|c|c|}
\hline Peak & R. Time & Area $\%$ & IUPAC name & Fatty acid \\
\hline 1 & 7.8850 & 37.10 & Dodecanoic acid & Lauric acid \\
\hline 2 & 11.0230 & 14.73 & Methyle tetradecanoate & Methyl tetradecanoate \\
\hline 3 & 15.2800 & 9.24 & Hexadecanoic acid & Palmitic acid \\
\hline 4 & 17.5500 & 4.33 & 9,12-Octadecanoic acid & Linoleic acid \\
\hline 5 & 17.6290 & 32.66 & 9- Octadecanoic acid & Oleic acid \\
\hline 6 & 17.9680 & 1.71 & Octadecanoic acid & Stearic acid \\
\hline \multirow[t]{2}{*}{7} & 21.9090 & 0.22 & Phthalic acid & 1,2 Benzendicarboxylic acid \\
\hline & & 100.00 & & \\
\hline
\end{tabular}

\section{DISCUSSION}

In this study it was found that the chemical constituents which are of interest were the fatty acids constituents and vitamin E content. The seeds oil can be considered a good source of lauric acid and Oleic acid (Omega-9). This is in agreement with the finding reported by (Besbes et al., 2005) for $\alpha$-tocopheral in their extracted seeds oils Table 1. It is worth noting that the content of Oleic acid and lauric acid in the Sudanese date seed oils were 37.10 and $32.66 \%$ respectively at a ratio of 1.136 . On the date seed oils reported by Devshony et al. (1992), they were (42.5\%) Oleic acid compared to $(21 \%)$ lauric acid at a ratio2:1. Table 1 also reflects that ALBarakawi summarised physico-chemical properties out-weigh those of Alguendela with the exception of stearic acid contents the other chemical constituent identified in the date seed oils was the naturally occurring antioxidant, vitamin $\mathrm{E}$ (tocopherols). Medically, vitamin $\mathrm{E}$ is a potent antioxidant that protects the body against oxidation reactions (radicals) that damage membranes 
cholesterol transporting lipoproteins. Other medical use cover activity as screening reagent protecting against skin damage and aging by UV radiation, inhibits growth of cancer cells and a protector against at herosclerosis by lowering cholesterol level (Packer, 1991; Traber et al., 1997; Sundram et al., 1989; Goh et al., 1994; Lercker and Rodriguez-Estrada, 2000; Ziegler and Filer, 1996; Rimm et al., 1993). The richest source of vitamins $\mathrm{E}$ or tocopherols in the diet is vegetable oils and their products including palm oil (Chiew et al., 2007). Tocopherol in date tocopherols in date seed oil are reported by (Besbes et al., 2005). In our study the date seed oil was also found to contain Vit E (Fig. 2a and b). The semi-solid nature of the oils is an indication of the presence of major saturated and unsaturated fatty acids (lauric acid and oleica cid respectively) The presence of $\alpha$-tocopherols in the oils is reflected by the coinciding retention times of $2.5 \mathrm{~min}$. for the standard and a corresponding peak in the sample chromatogram (Fig. 2a and 2b). sample chromatogram also shows a number of unidentified peaks which could include $(\alpha, \beta, \gamma, \delta)$ tocopherols. The content of $\alpha$ - tocopherols was estimated in this study to be about $6.054 \mathrm{ppm}$ in both studied seed oils compared to a $25-40 \mathrm{ppm}$ reported by (Besbes et al., 2005) for $\alpha$-tocopheral in their extracted seeds oils Table 1.

Table 3 shows the mass spectral assigments of major Vit $\mathrm{E}$ fragments depicted from Fig. 3.

The molecular ion at $430 \mathrm{~m} / \mathrm{z}$ corresponds to the molecular weight of tocopherol (430). The other fragments presented in the table collectively indicate the tocopherol structure.

Table 3: Shows the mass spectral assignments of major Vit E fragments

\begin{tabular}{ll}
\hline $\mathrm{M} / \mathrm{Z}$ & Species \\
\hline 430 & $\mathrm{M}^{+}$ \\
415 & $\left(\mathrm{M}-\mathrm{CH}_{3}\right)^{+}$ \\
205 & $\left(\mathrm{M}-\mathrm{C}_{16} \mathrm{H}_{33}\right)^{+}=\left(\mathrm{C}_{13} \mathrm{H}_{17} \mathrm{O}_{2}\right)^{+}$ \\
165 & $\left(\mathrm{C}_{10} \mathrm{H}_{13} \mathrm{O}_{2}\right)^{+}$base peak \\
85 & $\mathrm{C}_{6} \mathrm{H}_{13}^{+}$ \\
71 & $\mathrm{C}_{5} \mathrm{H}_{11}^{+}$ \\
57 & $\mathrm{C}_{4} \mathrm{H}_{9}^{+}$ \\
43 & $\mathrm{C}_{3} \mathrm{H}_{7}^{+}$ \\
29 & $\mathrm{C}_{2} \mathrm{H}_{5}^{+}$ \\
\hline
\end{tabular}

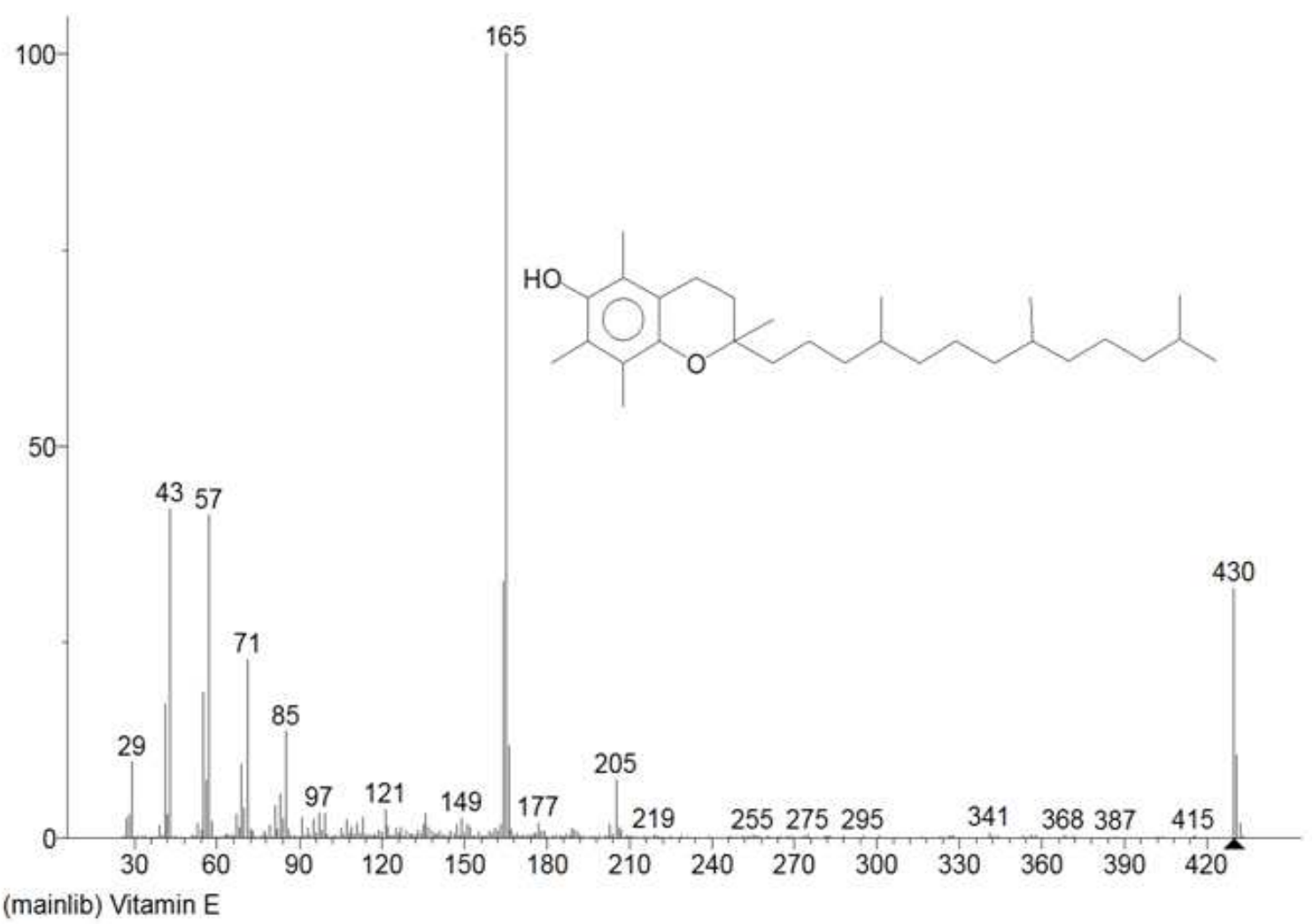

Fig. 3: Vitamin E identification in ALBarakawi and Alqundeila date seeds oil by GC-MASS 


\section{CONCLUSION}

The various constituents of date seed oils reported in this study, compared to previous studies $(2,6)$ done in different geographical areas confirmed similarity of the major constituents of date palm trees seeds oil whether grown in tropical or Mediterranean areas.

Joint with these previous studies date seeds oils potential use in industry (food, cosmetics, medicine and pharmaceutical) is promising.

\section{ACKNOWLEDGMENT}

The researchers would like to thank Prof. El Gaali Eisa, the previous director of the central laboratory, Ministry of Science and technology for the financial support.

\section{REFERENCES}

AOAC, 1990. Official Methods of Analysis. 1st Edn., Association of Official and Analytical Chemists. Washington, D.C., ISBN-10: 0935584439.

Besbes, S., C. Blecker, C. Deroanne, G. Lognay and N.E. Drira et al., 2005. Heating effects on some quality characteristics of date seed oil. Food Chem., $\quad 91$ : 469-476. 10.1016/j.foodchem.2004.04.037

Besbes, S., C. Blecker, C. Deroanne, G. Lognay and N.E. Drira et al., 2004a. Quality characteristics and oxidative stability of date seed oil during storage. Food Sci. Technol. Int., 10: 333-338. DOI: 10.1177/1082013204047777

Besbes, S., C. Blecker, C. Deroanne, N. Bahloulg and G. Lognay et al., 2004b. Date seed oil: Phenolic, tocopherol and sterol profiles. J. Food Lipids, 11: 251-265. DOI: 10.1111/j.1745-4522.2004.01141.x

Chiew, W.P., Y.M. Choo, A.N. Ma and H.C. Cheng, 2007. The effect of physical refining on palm vitamin E (tocopherol, tocotrienol and tocomonoenol). Am. J. Applied Sci., 4: 374-337. DOI: 10.3844/ajassp.2007.374.377

Devshony, S., E. Eteshola and A. Shani, 1992. Characteristics and some potential applications of date palm (Phoenix dactylifera L.) seeds and seed oil. J. Am. Oil Chem. Soc., 69: 595-597. DOI: 10.1007/BF02636115

E1-Shurafa, M.Y., H.S. Ahmed and S.E. Abou-Naji, 1982. Organic and inorganic constituents of date palm pit (seed) [in Libya]. Date Palm J., 2: 275284.
Goh, S.H., N.F. Hew, A.W. Norhanom and M. Yadav, 1994. Inhibition of tumour promotion by various palm-oil tocotrienols. Int. J. Cancer, 57: 529-531. DOI: 10.1002/ijc.2910570415

Harry, R.G., 1936. Some analytical characteristic of date stone oil. Analyst 61: 403. Nutrition Abstract, 6: 2-307.

Lercker, G. and M.T. Rodriguez-Estrada, 2000. Chromatographic analysis of unsaponifiable compounds of olive oils and fat-containing foods. J. Chromatography A, 881: 105-129. DOI: 10.1016/S0021-9673(00)00455-6

Mossa, J.S., M.S. Hifinawy and A.G. Mekkawi, 1986. Phytochemical and biological investigations on date seeds (Phoenix dactylifera L.) produced in Saudi Arabia. Arab Gulf J. Sci. Res., 4: 2-2.

Packer, L., 1991. Protective role of vitamin E in biological systems. Am. J. Clin. Nutr., 53: 1050S$1051 \mathrm{~S}$.

Price, W.J., 1979. Spectrochemical Analysis by Atomic Absorption. 1st Edn., Heyden, Philadelphia, ISBN10: 0855014555, pp: 392.

Rimm, E.B., M.J. Stampfer, A. Aschero, E. GlovannucclI and G.A. Golditz et al., 1993. Vitamin E consumption and the risk of coronary heart disease in men. N. Engl. J. Med., 328: 14501456. DOI: 10.1056/NEJM199305203282004

Salem, S.A. and S.M. Hegazi, 1971. Chemical composition of the Egyptian dry dates. J. Sci. Food Agric., 22: 632-633. $10.1002 /$ jsfa. 2740221207

Sundram, K., H.T. Khor, A.S.H. Ong and R. Pathmanathan, 1989. Effect of dietary palm oils on mammary carcinogenesis in female rats induced by 7,12-Dimethylbenz(a)anthracene. Cancer Res., 49: 1447-1451.

Traber, M.G., M. Podda, C. Weber, J. Thiele and M. Rallis et al., 1997. Diet-derived and topically applied tocotrienols accumulate in skin and protect the tissue against ultraviolet light-induced oxidative stress. Asia Pacific. J. Clin. Nutr.., 6: 6367.

Whaibi, M.H. and M.O. Basalah, 1986. Fatty acids in seeds of four cultivars of date palm tree. J. Coll. Sci., 17: 27-35.

Whaibi, M.H., M.O. Basalah and I.E. Al-Ackhal, 1985. Chemical composition of some date palm seeds. J. Coll. Sci., 16: 23-29.

Ziegler, E.E. and L.J. Filer, 1996. Present Knowledge in Nutrition. 7th Edn., ILSI Press, Washington, DC., ISBN-10: 0944398723, pp: 684. 